\title{
Cordéis Minimalistas
}

\author{
LUIZ FELIPE BOTELHO
}

Nasceu no Recife (PE), em 1959. É dramaturgo, mestre em Artes Cênicas (2007, UFBA), arquiteto (1983, UFPE), ator (1991, CFA/UFPE) e diretor de teatro. Trabalha desde 1993 na Massangana Multimídia Produções (MMP), produtora audiovisual da Fundação Joaquim Nabuco (FUNDAJ/MEC) onde, além de criar roteiros e dirigir séries e documentários para TVs educativas, criou e coordenou o projeto TelaTeatro (2008/2012, FUNDAJ/MEC). Este projeto manteve dois grupos de estudos (dramaturgia e trabalho do ator) voltados para a investigação e a prática na fronteira entre linguagens como teatro, cinema, TV, histórias em quadrinhos, videogames e RPGs. No teatro, Botelho escreveu 28 peças - 26 já encenadas, 5 premiadas e 6 publicadas ("Janos Adler", "Menino Minotauro", "Reis Andarilhos", "Mau Mau Miau", "Os errantes de Barramal", "Coiteiros de Paixões" e "O segredo da arca de Trancoso") - muitas delas contendo abordagens alegóricas e releituras de antigos mitos. Dentre seus trabalhos mais recentes estão: o livro "O jogo do ilimitado" (2007, Sesc) baseado no conteúdo de sua homônima dissertação de mestrado sobre flexibilização espaço-temporal na dramaturgia de João Falcão; e os DVDs Coleção Teatro - Volumes 1 e 2 (2009/2011, FUNDAJ), que reúnem documentários em vídeo sobre a produção teatral contemporânea local e nacional; os exercícios de criação no âmbito do projeto TelaTeatro, que incluem o espetáculo teatral transmidiático Os que vivem dentro de nós (2011) e vários vídeos veiculados pela internet, como a websérie Stufana (www.stufana.blogspot.com) (2010) e a série de improvisos "Sushi de Cena" (acesso via YouTube) (2010/11); e o registro em vídeo de Deus Danado, premiada encenação caruaruense produzida pela Cia Arte em Cena (2011/2012). 


\section{Apresentação: Cordéis Minimalistas - o que são e como surgiram}

Os textos da série "Cordéis Minimalistas" foram criados pelo dramaturgo pernambucano Luiz Felipe B otelho durante a realização do Projeto Paisagem Zero, evento promovido pelo SESC Pompéia (SP) e pela Fundação Joaquim Nabuco em 2002. Esse projeto, que se desenvolvia em torno de dez temas ${ }^{1}$, envolvia várias oficinas e núcleos de criação com a participação integrada de artistas de várias regiões e tendências estéticas, buscando uma antevisão das possibilidades da realização artística no novo milênio. O título "Cordéis Minimalistas" evocava os artistas populares e sua capacidade de improvisar a partir de temas propostos, lançando sobre eles um olhar crítico e, sobretudo, bem humorado.

O núcleo dos "Cordéis Minimalistas" envolveu, além de Botelho, vários cordelistas (como J. Borges, Jailson Nascimento, Manoel Inácio e outros), o encenador português João Mota e os atores também pernambucanos Adelson Dornellas, Ana Nogueira, Ana Maria Ramos, Augusta Ferraz, Andrezza Alves, Jorge Clésio e Márcio Carneiro.

Cada tema do Projeto Paisagem Zero serviu como mote aos cordelistas e ao dramaturgo. Enquanto os primeiros criaram cordéis completos a partir daqueles temas, coube a Luiz Felipe Botelho criar peças que durassem em torno de dez minutos, em gêneros e abordagens que ele mesmo escolheria. Porém, enquanto os autores de cordel tiveram tempo livre para suas criações, o encenador João Mota, inspirado nos desafios dos repentistas, propôs a Botelho que o tempo máximo para criação de cada texto fosse de vinte e quatro horas, introduzindo um caráter de improviso que também se encaixava com a proposta do projeto. Esse desafio não era somente para quem escrevia. Os atores também tiveram tempo restrito para lidar com as peças. $\mathrm{Na}$ medida em que iam sendo concluídas, cada uma delas era repassada para o encenador e o elenco, e eles começavam a trabalhar aquele conteúdo. Nessa dinâmica, o dramaturgo comparecia aos ensaios e trocava ideias com atores e encenador, de modo que cada texto ainda podia ser ajustado para atender ao que surgia durante o processo de encenação.

Assim, foram criados dez textos, dos quais sete ${ }^{2}$, marcadamente cômicos, estão reunidos nesta edição especial da Revista OuvirOUver: "Fundação" (alegoria sobre o "achamento" do Brasil), "Origem" (homem visita mulher trazendo misteriosas revelações), "Criança" (dois meninos ponderam sobre as vantagens e desvantagens de ser criança), "Transbordamento" (guardas de uma imensa represa tentam superar permanente estado de tensão), "Códigos" (soldados no campo de batalha vêem-se ameaçados pela falta de comunicação), "Dissolução" (casal de homens contrata juiz para obter uma separação) e "Inquisição" (programa de auditório situa a Inquisição em nossa época). Esses textos foram originalmente encenados dentro do próprio Projeto Paisagem Zero, em novembro de 2002. O encenador João Mota optou por uma proposta de teatro de rua que foi apresentada nas dependências do Sesc Pompéia, juntamente com a leitura de trechos dos cordéis sobre os temas correspondentes.

\footnotetext{
Os temas/textos eram dez, dos quais sete estão incluídos aqui: Fundação, Origem, Criança, Transbordamento, Códigos, Dissolução e Inquisição.

2 Os outros três textos ("Purificação", "Ritos de passagem"e "Fim") foram posteriormente separados do conjunto pelo autor e desenvolvidos como textos independentes.
} 


\section{Fundação}

Personagens:

BAIACURU - líder tupiniquim

PETER PINZON - empresário estrangeiro

ARCANJO GABRIEL

SATANÁS

(Baiacuru entra pisando forte, com a cara amarrada, feito menino emburrado. Depois chega Peter)

PETER - Ô, Baiacuru, não fica assim, vai.

BAIACURU - Peter Pinzon, você é muito falso.

PETER - Falso por que?

BAIACURU - Como é que você, depois de toda a hospitalidade que recebeu aqui, tem coragem de fazer o que fez com aquela bandeira da Global Corporation, na frente de toda a minha tribo?

PETER - Mas o que eu fiz não foi nada de mais.

BAIACURU - Nada de mais? (Tentando se controlar) Você enfiou a porra do mastro da bandeira no chão e disse que o nome desta terra agora vai ser Brasil! Isso não é nada de mais?

PETER - Eu não fiz isso, não.

BAIACURU - Não fez? Então dez mil tupiniquins mascaram coca e tiveram uma alucinação coletiva.

PETER - Não é isso.

BAIACURU - Todos nós ouvimos muito bem, seu Peter Pinzón. Brasil, você falou. Brasil! PETER - Brasil, sim. Uma homenagem ao precioso pau avermelhado que aqui dá em abundância.

BAIACURU - O nome deste lugar foi, é e sempre será Pindorama, a Terra das Palmeiras. Isso desde muito antes do tempo do avô do meu avô.

PETER - Eu sei, amigo. Mas você realmente entendeu errado. O oba-oba que fizemos com aquela bandeirinha besta foi só uma daquelas atividades protocolares que a gente é obrigado a fazer em todo lugar que chega. Um ritualzinho de fundação, para tirar umas fotos, guardar de lembrança e pronto. Bobagem pura, nem ligue.

BAIACURU - Ligo, sim. Você falou em fundação. Fundação de que?

PETER - Fundação da empresa Brasil S/A! Homem, já se esqueceu? A gente não tinha combinado que ia montar um negócio juntos? Que íamos juntar nossos potenciais em benefício de nossos povos? Nós entramos com nosso know-how de comerciantes e vocês entram com essa qualidade inata de grande fornecedor de matéria-prima e mão-de-obra. Eu lhe disse que faremos deste lugar uma terra ainda melhor do que é, não disse?

(Baiacuru não responde, cheio de dúvidas, olhando fixamente para Peter Pinzon, que, após breve pausa, retoma o pique, evitando que Baiacuru pense demais) 
PETER - Não faça essa cara para mim, meu amigo. Sei que você tem uma excelente memória. Nós conversamos longamente sobre tudo isso - conversamos sobre isso ou não?

(Mal Baiacuru tenta responder, Peter prossegue ágil, metralhadora de palavras nitidamente audiveis e compreensíveis)

PETER - Claro que conversamos, você sabe disso. Não há tempo a perder. O mundo precisa de homens que ajam rápido, que tenham atitude, e eu sei que você é um homem assim. É ou não é?

BAIACURU - Sou, mas...

PETER - Eu sei que é. Sempre soube. Está estampado nesta face impávida, colosso de criatura latino-americana, raça do futuro preconizada nas sagradas escrituras de antanho. Por isso me é impossível aceitar a idéia de que, por um instante que seja, tenha passado pela sua cabeça que não deseja mais trabalhar em parceria com a Global Corporation.

BAIACURU - Bem, é que o nome desta terra é Pindorama e...

PETER - Nem ligue para o que eu disse. Brasil é só nome de fantasia, mas a razão social continua a ser Pindorama.

BAIACURU - Não entendo isso.

PETER - O nome de fantasia é aquele que a gente usa para vender a idéia e a razão social é o que fica nos papéis, mantido como lembrança da nossa tradição.

BAICURU - Que idéia interessante.

PETER - Também acho.

BAIACURU - Mas ainda existe o risco das pessoas esquecerem a razão social.

PETER - O social, até acho provável que esqueçam, mas a razão, somente se a coisa piorar muito.

BAICURU - Ainda não sei se compreendo.

PETER - Entregue-se, homem, jogue-se na voragem da vida. Acredite em você! (Cutucando Baiacuru) Dá um sorriso daqueles pra mim, dá. Dá. Vai Baiá. Vai, vai, vai. BAIACURU - (Olhando ao redor, querendo rir, tentando se conter) Para com essa viadagem, Peter, tem gente olhando.

PETER - Estou esperando aquele sorriso lindo que só você sabe dar por estas bandas. Cadê ele? Cadê? Hem?

(Baiacuru fica todo encabulado, fazendo um esforço tremendo para ficar sério e manter a pose. Peter não Ihe dá sossego)

BAICURU - Pare, ouviu? Vou danar-Ihe a borduna!

PETER - Cadê o sorrisinho dele que eu quero ver?

BAIACURU - (Sem conseguir se impor, prendendo o riso) Eu já disse que pare.

PETER - Cadê, cadê, cadê? Cadê, cadê, cadê? (Cutucando Baiacuru)

BAIACURU - Sai, Peter, pára! Eu tenho cócegas!

PETER - Sorriso, sorriso, sorriso.

BAIACURU - Está aqui, pronto. (Dá um sorriso)

PETER - Lindo. Assim é que é bom. Está mais tranquilinho?

BAIACURU - (Dá um suspiro e responde) Estou.

PETER - Tranquilo mesmo? Acabou o mal-entendido? 
BAIACURU - Acabou.

PETER - Agora só falta você assinar aqui, para tudo ficar sacramentado.

(Luzes, trombetas, orquestra triunfante. Baiacuru se assusta, Peter percebe o que se passa e fica irado. Surge o Arcanjo Gabriel, interpretado por uma mulher, tomando o contrato das mãos de Peter Pinzón)

ARCANJO GABRIEL - Não assine, Baiacuru.

PETER - (Retendo a vontade de explodir e agredir o Arcanjo) liiih.

ARCANJO GABRIEL - (Para Peter Pinzón) liiih, nada, meu amigo.

BAIACURU - Quem é você?

ARCANJO GABRIEL - Sou o Arcanjo Gabriel. Trabalho com Dr. Tupã.

BAIACURU - Ah, sim, claro.

(Enquanto Gabriel e Baiacuru conversam, Peter se recompõe, preparando-se para contra-atacar)

ARCANJO GABRIEL - Ele me encarregou de vir aqui e lhe dar uma assessoria na assinatura desse contrato.

PETER - Detesto essa ingerência de instâncias superiores. Burocracia inútil que só faz atrasar processos.

ARCANJO GABRIEL - Baiacuru não tem experiência administrativa. Precisa de um assessor competente, alguém que impeça que certas corporações tentem se aproveitar deste líder usando da boa fé que ele tem.

PETER - Acontece que neste contrato que vamos assinar, as duas partes se beneficiarão.

ARCANJO GABRIEL - A sua parte mais do que a parte dele.

PETER - Que coisa antiga, Gabriel! Você ainda está operando no velho paradigma, não consegue relativizar as coisas. Para quem observa do ponto de vista ocidental, é claro que a parte que nos cabe pode parecer muito, mas muito maior do que a dele. Mas tente ver as coisas por uma perspectiva mais ampla: Baiacuru e o povo dele não fazem questão de muita coisa. Eles são felizes com pouco ou quase nada. Por que devemos destinar um volume de ganhos que eles nem acreditam que merecem? Conceitos como riqueza ou pobreza, isso para eles não faz a menor diferença. ( $A$ Baiacuru) Estou mentindo, Baiacuru? Você mesmo não me disse que já tem tudo o que deseja da vida?

BAIACURU - Disse.

PETER - (Vitorioso, para Gabriel) Está vendo?

ARCANJO GABRIEL - Vejo tudo, Peter Pinzon! Tudo! Baiacuru não vai assinar um documento nesses termos.

BAIACURU - Que termos?

PETER - (Colocando-se entre Baiacuru e Gabriel) Você não pode obrigar o homem a desejar o que ele não quer desejar.

BAIACURU - Qual é o problema? O que está acontecendo?

(Estrondo, luzes enfraquecem por alguns instantes, como se houvesse alguma falha no sistema elétrico. Entra Satanás, também interpretado por uma mulher.)

SATANÁS - Problema nenhum, Baiacuru. (Puxa Baiacuru para o lado) Venha aqui um instantinho conversar comigo. 
ARCANJO GABRIEL - (Afastando Satanás de Baiacuru) Tire os cascos de cima dele, irmãozinho.

BAIACURU - Vocês são irmãos?

SATANÁS - Por parte de pai.

BAIACURU - (Olhando para as asas de Gabriel e para os chifres de Satanás) São muito diferentes um do outro.

ARCANJO GABRIEL - Ele ganhou esses chifres depois de uma queda que levou, tempos atrás.

SATANÁS - (Saca um cartão de visitas para Baiacuru e outro para Peter) Satanás da Silva, consultorial infernal, às suas ordens.

ARCANJO GABRIEL - (Tomando o cartão de Satanás antes que Baiacuru o toque) Não toque nisso, meu filho.

(Gabriel rasga o cartão. Satanás tira outro e tenta passá-lo para Baiacuru. Gabriel continua tentando impedir, interceptando o cartão e rasgando-o em seguida. Esse jogo entre Satanás e Gabriel continua. Baiacuru está curioso e faz um esforço para pegar o cartão.)

ARCANJO GABRIEL - Vá embora, Satanás. Ninguém quer você aqui.

PETER - (Avançando para ajudar) Eu quero.

ARCANJO GABRIEL - Recue, Peter Pinzon! Dois contra um não vale.

PETER - Dois contra dois.

ARCANJO GABRIEL - Dois contra um! É óbvio que, neste jogo, Baiacuru é a bola.

SATANÁS - Ai, Gabriel, você não tem competência para gerir um processo deste nível.

ARCANJO GABRIEL - Tenho três doutorados, dois pós-docs e quinze livros publicados!

SATANÁS - Sobre o que? Sobre a brancura das nuvens? A nudez dos anjos barrocos?

ARCANJO GABRIEL - Que tal "meandros da manipulação e exploração subreptícia de indivíduos no contexto universal da luta de classes"?

SATANÁS - Ai, acho tão antiga essa história de luta de classes.

ARCANJO GABRIEL - Antigo é esconder os fatos debaixo do tapete. Já viu o estado deste planeta? Claro que viu, você está adorando a situação.

SATANÁS - O seu problema é seu pessimismo, essa negatividade. O mundo está sempre mudando. E para melhor!

(Gabriel dá um suspiro, incrédulo)

SATANÁS - Melhor pra mim, e daí? Tem que ser melhor para alguém.

(Satanás dá um cartão para Peter, que consegue entregá-lo a Baiacuru. Satanás sorri)

SATANÁS - Além do mais, o que tem de ser, será! (À Peter) Obrigado, amigo.

ARCANJO GABRIEL - Jogo roubado, qualquer um ganha.

SATANÁS - Isto não é um jogo, Arcanjo, é o Teatro da Guerra.

BAIACURU - (Jogando o cartão fora) Não tem especial nisso aqui.

SATANÁS - Melhor assim, não é, Gabriel?

ARCANJO GABRIEL - (Irritado, à Baiacuru) Venha, meu filho. Precisamos conversar. (Puxa o índio para o lado para conversar.)

SATANÁS - Que anjo antipático. (A Peter) É o tipo de gente que não aceita mudanças, percebe?

PETER - Sempre desejei conhecê-lo pessoalmente, Dr. Satanás. O professor Belze- 
bu já havia me falado muito a seu respeito.

SATANÁS - De onde conhece meu avô?

PETER - Foi orientador da minha tese de Doutorado em Cambridge.

SATANÁS - Mentira!

PETER - Verdade!

SATANÁS - Coincidência maravilhosa.

(Satanás e Peter apertam as mãos e, juntos, afastam-se um pouco conversando animadamente. Enquanto Gabriel e Baiacuru conversam, os gestos da conversa de Peter e Satanás darão a entender que estes combinam um plano para obter a assinatura de Baiacuru)

ARCANJO GABRIEL - Se você assinar esse papel, vai ter dificuldades para voltar atrás.

BAIACURU - Tudo o que eles querem é pau-brasil e aqui tem muito. É o bastante para nós e para eles.

ARCANJO GABRIEL - E isso aqui?

BAIACURU - Eu não sei ler.

ARCANJO GABRIEL - Ah, desculpe. Aqui diz o seguinte: "a Global Corporation não se responsabiliza em absoluto pelo que possa vir a acontecer com a alma dos habitantes desta terra após a assinatura deste contrato".

BAIACURU - E o que é tem de mais? Cada povo deve mesmo se responsabilizar por sua própria alma.

ARCANJO GABRIEL - Mas o que o contrato diz é que qualquer coisa poderá acontecer com vocês. Qualquer coisa, mesmo. Compreende?

BAIACURU - Coisas muito boas, Peter falou.

ARCANJO GABRIEL - E coisas muito más.

BAIACURU - É um risco. A vida não é assim? Cheia de coisas boas e más?

ARCANJO GABRIEL - (À parte) Meu Deus, me ajude a me fazer entender. (Decidindo apelar para um último recurso não muito agradável para si) Eles vão fazer vocês trabalharem para eles pagando uma ninharia.

BAIACURU - Ô! Uma comidinha e um cantinho pra morar está bom demais.

ARCANJO GABRIEL - Junto com o pau brasil, vão destruir essas florestas, cortar as árvores todas, sujar os rios, acabar com os animais.

BAIACURU - Quem? Acabar com esse florestão? Sujar um rio deste tamanho? Duvido! ARCANJO GABRIEL - Vão trazer religiões diferentes, costumes que não tem nada a ver com este lugar. Vocês vão ser obrigados a aceitar essas coisas e ver tudo isso ocupar o lugar da tradição que vocês construíram.

BAIACURU - (Olha rindo para Gabriel) Que viagem, criatura! Tu fumaste um antes de vir pra cá, não foi? Ninguém tem tanto poder pra fazer isso, não.

ARCANJO GABRIEL - Você não acredita em mim?

BAIACURU - Olhe, ... como é mesmo seu nome?

ARCANJO GABRIEL - Gabriel.

BAIACURU - Olhe, Gabriel, acredito que você acredita no que diz. Mas não consigo imaginar que seja possível uma situação tão horrível assim. Talvez seu irmão tenha razão. Você vê tudo com uma energia muito negativa. Temos que acreditar no amanhã. Este lugar tem um grande futuro e é nesse futuro que quero botar os meus pés. ARCANJO GABRIEL - Só existe o presente, Baiacuru. O resto é abstração.

(Sataná.s se aproxima) 
SATANÁS - Vê como ele é pessimista? Tentei avisar que esse meu irmão não bate bem do juízo. Cuidado com ele.

ARCANJO GABRIEL - Saia daqui, Satanás. Ainda não terminei minha conversa. SATANÁS - (A parte, para Baiacuru, referindo-se a Gabriel) Ele trabalha demais. ARCANJO GABRIEL - Tente não ouvir o que ele diz, Baiacuru.

BAIACURU - (Para Gabriel) Como eu faço isso?

SATANÁS - (Para Baiacuru) Meu maninho está muito estressado, o astral lá em baixo. BAIACURU - Notei.

SATANÁS - (Para Gabriel) Não fica bem obrigar uma pessoa (dá uma rápida olhada cúmplice para Baiacuru, que fica intrigado tentando perceber as entrelinhas da frase de Satanás) a fazer aquilo que você acha que está certo...

(Gabriel avança para Satanás, puxando a espada e interpondo-se entre este e Baiacuru)

ARCANJO GABRIEL - Não fale mais nada, ouviu, cobra? Minha paciência acabou para você. Vá embora! Vá!

SATANÁS - Viu, Baiacuru? Se ele trata o irmão assim, avalie o que não reserva para o resto dos pobres mortais.

ARCANJO GABRIEL - (Para Baiacuru) Não ouça o que ele diz!

BAIACURU - (Irritado com a ordem do Arcanjo) Como, se eu já ouvi?

SATANÁS - (Para Baiacuru) Viu como ele é louco? Não fala nada com nada.

ARCANJO GABRIEL - (Brandindo a espada) Saia daqui!

SATANÁS - Já saí, já saí.

(Gabriel volta-se para Baiacuru e, por trás do arcanjo, Peter faz um sinal de "calma, está tudo certo" para Baiacuru. Este retribui. Gabriel olha para trás. Peter disfarça.)

ARCANJO GABRIEL - (Para Baiacuru, guardando a espada na bainha) Aceita pelo menos que eu ajuste o contrato para proteger os direitos de vocês?

BAIACURU - Não sei. Fiquei com raiva de Peter Pinzón por causa daquela história de querer mudar o nome da nossa terra, mas ele já explicou, já esclareceu. Será que vale a pena a gente ficar brigando por bobagem?

ARCANJO GABRIEL - Mas, Baiacuru, estamos falando de oito mil quilômetros quadrados de território repletos de riquezas. Que contrato absurdo é esse onde vocês perdem mais do que ganham?

(Peter e Satanás se aproximam)

PETER - Desista, Arcanjo.

ARCANJO GABRIEL - O que me diz, Baiacuru?

BAIACURU - "Não fica bem obrigar uma pessoa a fazer aquilo que você acha que está certo..."

(Gabriel afasta-se, altivo, e fica observando de perto)

SATANÁS - Assine, Baiacuru. Assim iremos todos embora e deixaremos vocês em paz.

(Baiacuru sorri. Olha para Satanás e para Peter)

ARCANJO GABRIEL - (Para Baiacuru, sem conseguir se conter) Não... não...

BAIACURU - Eu... não sei assinar meu nome.

PEDRO - (Tirando uma almofada de carimbo do bolso) Mas tem um lindo polegar. Veja o que faço com o meu. (Inicia uma demonstração, como a mis-en-céne de um bom vendedor) Basta passar tinta, assim, e marcar o papel com ele. (Estende a mão 
para Baiacuru, pedindo-Ihe o polegar) Posso?

(Baiacuru estende o dedo. Gabriel suspira, dando-se por finalmente derrotado. Afasta-se um pouco mais, para e continua a observar. Peter conclui a "assinatura" do contrato.)

PETER - (Para Satanás) Testemunha?

SATANÁS - Com prazer. (Pega uma caneta e assina também) (Saindo, exultantes e apressados)

PETER - Obrigado, Baiacuru. Foi um prazer fazer negócio com você.

SATANÁS - Adeus, meu querido. Precisando de mim, é só chamar, tá?

(Satanás se afasta, fazendo gestos de deboche para Gabriel. Peter sai de cena comemorando)

PETER - Yes! Yes! Yes!

(Gabriel olha tudo de longe, arrasado e em silêncio)

BAIACURU - Esses caraíbas pensam que somos tolos. Coitado daquele Gabriel, tanto estresse sem necessidade. Ele não sabe que somos muitos? Se alguma coisa não der certo nesse contrato, sempre restarão a nossa coragem guerreira e os nossos arcos e flechas, sempre prontos para lutar e vencer.

\section{origem}

\section{Personagens:}

NEEMIAS

GALIANA

(Galiana está em casa, à noite, e recebe uma visita misteriosa. Está tossindo. É uma mulher jovem e adoentada)

NEEMIAS - Sou eu, Galiana. Deixe-me entrar.

GALIANA - Neemias! O que faz aqui uma hora destas? Já soou o toque de recolher, você não ouviu?

NEEMIAS - Preciso muito falar com você.

GALIANA - O que houve? Aconteceu alguma coisa com a minha irmã? Fale, é algo com Virgínia ou com os meninos?

NEEMIAS - Estão todos bem. Dormem como anjos.

GALIANA - Então?

NEEMIAS - Deve se preparar para ouvir o que tenho a dizer.

GALIANA - Ah, por favor, se é uma notícia de morte, fale de uma vez.

NEEMIAS - É uma notícia de vida que estou trazendo.

GALIANA - Você está diferente. Até o jeito de falar parece ter mudado. Venha mais para cá, para perto da luz. (Puxa-o até um lugar mais iluminado e volta a examiná-lo) Sim. É você mesmo. Mas existe algo estranho que eu...

NEEMIAS - É sobre isso que quero falar. Existe algo em mim que mudou.

GALIANA - Você está me assustando. (Tosse) Diga logo o que veio fazer aqui ou então vá embora. 
NEEMIAS - Não sou mais Neemias, Galiana. Algo extraordinário aconteceu comigo. GALIANA - É tarde. Não devia usar o horário de descanso para brincadeiras. Não sabe que ando adoentada?

NEEMIAS - Sei. É por isso que vim.

(Silêncio. Olham-se por instantes)

GALIANA - Você não está brincando, posso ver nos seus olhos.

(Galiana se afasta, tossindo)

NEEMIAS - O que foi?

GALIANA - Tudo isso me deixa cada vez mais aterrorizada. Conte-me logo o que se passa.

NEEMIAS - Eu estava assistindo o jornal e aí senti uma coisa estranha aqui no peito.

GALIANA - Coisa estranha?

NEEMIAS - Uma dor.

GALIANA - O coração?

NEEMIAS - Sim.

GALIANA - Dor de paixão?

NEEMIAS - Dor de morte.

GALIANA - (Tem um pequeno susto, tosse) E o que fez?

NEEMIAS - Não pude fazer nada. Até pensei em pedir ajuda, mas...

GALIANA - O que aconteceu, então?

NEEMIAS - Minha visão ficou turva por alguns instantes.

GALIANA - (Toca o rosto de Neemias) Não. Você não é um fantasma.

NEEMIAS - Não. Eu não morri, Galiana.

GALIANA - Está se sentindo bem, agora? O desconforto passou?

NEEMIAS - Tudo passou. Eu perdi os sentidos e depois acordei.

GALIANA - E daí? Não sei se compreendo o que quer me dizer.

NEEMIAS - Não há muito mais a falar.

GALIANA - Você ainda não disse o mais importante, não é?

NEEMIAS - Não.

GALIANA - Então diga.

NEEMIAS - Não é algo que se possa dizer assim, de modo súbito.

GALIANA - Não agüento mais a tensão. Diga logo. De uma vez.

NEEMIAS - Eu sou Deus.

GALIANA - Sim... quer dizer... como?

NEEMIAS - Eu sou Deus.

GALIANA - (Rindo) Deus? Você? (Tem um ataque de riso)

NEEMIAS - Aguardarei que você se reestabeleça do choque.

GALIANA - (Rindo) Que choque, Neemias? Essa piada é ótima! Essa cara de bobo que você está fazendo. Amei. Mas, podia ter esperado para me pregar essa peça amanhã de manhã.

NEEMIAS - Tive um alumbramento.

GALIANA - (Rindo) Pára, criatura. Não agüento mais. Pára. (Tosse sem parar, começa a se sentir sufocada)

(Neemias segura o rosto de Galiana e dá-Ihe um tórrido beijo na boca.

Ela para de tossir)

NEEMIAS - Eu sou Deus.

GALIANA - (Chocada) Você está falando sério? 
NEEMIAS - Eu sou Deus.

GALIANA - Afaste-se de mim, por favor, está bem?

NEEMIAS - Compreendo que você me ache louco, mas é a verdade. E há outras verdades que você precisa saber.

GALIANA - Não quero saber verdade nenhuma.

NEEMIAS - Eu sabia que você não acreditaria.

GALIANA - Não precisa ser Deus para deduzir isso.

NEEMIAS - (Aproximando-se de Galiana) Posso provar o que digo.

GALIANA - Fique longe! Fique longe.

NEEMIAS - Deixe-me provar que sou Deus.

GALIANA - Prove daí mesmo.

NEEMIAS - Dê uma sugestão.

GALIANA - Sugestão? E eu sei lá.

NEEMIAS - Qualquer coisa que faça você acreditar em mim.

GALIANA - (Pensativa) Está bem... Quero um milhão de dólares, aqui, na minha mão.

NEEMIAS - Não posso.

GALIANA - Olhe aí!

NEEMIAS - Sim, porque é aí que está a outra verdade que eu preciso lhe contar.

GALIANA - Como assim?

NEEMIAS - Você também é Deus. Não posso lhe dar o que você não crê que merece ganhar.

GALIANA - (Fingindo, cautelosa, sem querer provocar Neemias, que ela crê estar totalmente enlouquecido) Acha mesmo que sou Deus também?

NEEMIAS - Só existem certezas em mim e em você. Aceite essa possibilidade e verá. GALIANA -Oooh! Que maravilha, Neemias. Somos Deus. Oh. Essa revelação me deixou tão atordoada. É melhor que você vá para sua casa. Precisamos dormir depois de tantas surpresas.

NEEMIAS - A calcinha que você está usando foi comprada há dois anos num camelô da rua Direita, é preta, confortável, tem dois remendos, e uma mancha de água sanitária em cima da nádega esquerda. A mancha a empregada fez sem querer, embora você tenha mandado ela embora acreditando que tivesse sido de propósito.

(Galiana fica estarrecida, sem saber o que fazer e acaba dando uma tapa na cara de Neemias)

GALIANA - Não tem vergonha de investigar sobre a vida das minhas calcinhas?

NEEMIAS - Nenhum detetive deste mundo poderia saber o que sei sobre a sua calcinha, Galiana. A não ser que esse detetive também descubra que é Deus.

GALIANA - Não pode ser. Eu devo estar sonhando.

NEEMIAS - O seu sutiã não combina com a calcinha. O que fazia par com a calcinha preta se rasgou e não teve mais conserto. Como você adora essa calcinha preta, não se importa em usar sutiã de outra cor. E hoje de manhã, quando você foi tomar banho...

GALIANA - Sempre tomo banho todas as manhãs.

NEEMIAS - Você se masturbou com a mangueirinha enquanto ficava imaginando que estava...

GALIANA - É melhor parar por aí. Certamente você não é o mesmo Neemias que conheço.

NEEMIAS - Nunca mais serei. 
GALIANA - Que truque bem feito. Você vai ter que me ensinar como faz isso.

NEEMIAS - Não há truque.

GALIANA - Claro que há.

NEEMIAS - Você não está convencida porque está pensando em porque não posso Ihe dar o milhão de dólares, não é?

GALIANA - Pare de ler minha mente, meu Deus, quero dizer, Neemias.

NEEMIAS - Parei, parei.

GALIANA - Mas eu realmente gostaria muito de ter um milhão de dólares. Se fosse

Deus, me daria.

NEEMIAS - Você não ganhou até hoje. Por que ganharia agora?

GALIANA - Sim, por que? Se sabe, me responda.

NEEMIAS - Você também é Deus, mas não tem consciência disso. A sua vida é o reflexo das suas crenças mais profundas. Não posso lhe dar um milhão de dólares porque, no fundo, você não acredita que isso seja possível. É você quem cria e mantém a forma disso que chamamos de "sua vida".

GALIANA - Filosofia barata, Neemias!

NEEMIAS - Física quântica, Galiana.

GALIANA - Onde você anda lendo essas coisas?

NEEMIAS - Tudo está em mim, em você, em toda parte. Não há limites, Galiana. É tudo feito de luz.

GALIANA - Que sonho bonito, esse. Ah, se fosse como você diz. Eu mesma, se eu fosse Deus, eu seria rica. Muito rica.

NEEMIAS - E é. Tudo o que existe lhe pertence.

GALIANA - Você sabe que isso não é verdade.

NEEMIAS - Um mundo que não pertença a Deus não passa de uma ilusão. O mundo que você vê não lhe pertence porque não existe.

GALIANA - E onde está o meu mundo, então?

NEEMIAS - Está aqui, escondido por um cenário de ilusões. Você o verá quando desistir de acreditar no que não faz sentido. Isso parece familiar para você?

GALIANA - Nem um pouquinho.

NEEMIAS - (Sem nem ligar para o comentário) Você pensava nessas coisas há muitos anos, ainda criança, pouco antes de dormir ou logo depois de acordar. Depois cresceu, as informações se multiplicaram, se confundiram e você nunca mais soube distinguir o que verdadeiramente vinha de você.

GALIANA - Deve parar de falar, agora. Suas palavras estão me deixando tonta.

NEEMIAS - Não faça nenhum esforço. Aceite minhas palavras. Deixe que elas resgatem sua alma, sua vida.

GALIANA - Tenho medo do que você diz, gentil cunhado. Minha intuição parece prever mudanças radicais em minha existência. Não me sinto bem. Por favor, vá embora. Se é mesmo Deus, como insiste em afirmar, deve saber que sofro de neo-tuberculose. Posso morrer se emoções fortes me acometerem.

NEEMIAS - Isso não acontecerá. Eu a curei com o meu beijo e com a força oculta em seu desejo inconsciente de ser curada por mim.

GALIANA - Ninguém pode me curar.

NEEMIAS - Vê. A sua tosse passou e você não percebeu. É esse descaso com a sua própria força que nos afasta, que impede que eu e você sejamos um.

GALIANA - Do que está falando? Será uma declaração de amor? 
NEEMIAS - É sim.

GALIANA - (Voltando a tossir) Isso é um absurdo.

NEEMIAS - Aceite o meu amor. Aceite a possibilidade de cura.

GALIANA - Mas eu não gosto de você.

NEEMIAS - Gosta, sim. Sempre gostou. Mesmo sabendo que sou o marido de sua irmã, que sempre fui mulherengo, que me enchia de cerveja todo final de semana. Mesmo sendo testemunha de que nas madrugadas de bebedeira, fazia xixi no portão de entrada de sua casa, como um cão que marcava o próprio território. Mesmo assim, você sempre gostou de mim.

GALIANA - Você não devia saber disso.

NEEMIAS - Sou Deus. Agora sei de tudo.

GALIANA - Não devia valer-se de suas prerrogativas divinas para sondar meus sentimentos mais íntimos. Que isso também lhe sirva para ver que posso trair a minha irmã mais amada.

NEEMIAS - Não há traições. Só o amor é real.

GALIANA - Diga isso antes para minha irmã. Verá o que ela pensa de um marido infiel e de uma irmã que não é digna de ser por ela respeitada.

NEEMIAS - Não tenha medo. Nada acontecerá. Eu vi o amanhã descortinando-se além das raízes do eterno aqui-agora. Faremos o que é justo e certo.

GALIANA - (Tosse) Não posso. Não posso.

NEEMIAS - Embora deseje este homem com todas as suas forças.

GALIANA - Não tenho mesmo segredos para você. Foi por isso que resolveu vir até aqui? Só para dizer que me amava?

NEEMIAS - Não. Vim para gerar um filho em seu ventre.

GALIANA - Deve parar de falar nesses assuntos da carne. A tentação já está a me deixar trêmula e frágil. Vejo-me prestes a cometer um desatino sem tamanho.

NEEMIAS - Que seja atendida cada súplica de sua carne, pois não se trata de um desatino, mas do cântico do destino anunciando a consumação de profecias perdidas na noite dos tempos.

GALIANA - Nesta situação, fatos carnais, como este que estamos prestes a protagonizar, configuram-se como pecados. Afinal você, digo, o Senhor, é casado com minha irmã.

NEEMIAS - Crê que eu sou Deus?

GALIANA - Não sei como e nem porque, mas, sim, eu creio.

NEEMIAS - Pois todos os teus pecados estão perdoados. Ficará mais tranquila se eu Ihe disser que a criança que carregará em seu ventre poderá salvar o mundo?

GALIANA - De que modo? Tantos já tentaram sem sucesso... Ninguém pode salvar o mundo...

NEEMIAS - Essa criança não acreditará nisso. Por essa razão, o mundo será salvo sem que ela precise mexer um dedo.

GALIANA - E eu?

NEEMIAS - O que quer saber?

GALIANA - Você me ama, realmente?

NEEMIAS - Com todo meu espírito.

GALIANA - Não é o que quero saber. Fale-me deste corpo de onde você se expressa. $\mathrm{O}$ que sente com ele? O que ele diz quando sente o meu calor penetrar-lhe a pele? NEEMIAS - De onde pensa que vêm os prazeres de um corpo? Amo você com todo 
meu ser. Peço-te, agora, que aceite ser curada. Preciso de uma mãe forte e saudável para criar os gêmeos que salvarão o mundo.

GALIANA - (Tosse) Gêmeos? Não era só um?

NEEMIAS - São dois.

GALIANA - Por que não disse logo?

NEEMIAS - Deve compreender que não posso revelar tudo de uma vez. Tantas revelações podem induzi-la a crer ainda mais na sua própria fragilidade.

GALIANA - Claro. Mas devo dizer-Ihe que gosto da idéia dos gêmeos. Tem mais alguma surpresa para mim?

NEEMIAS - Só mais uma. É que algumas partes do meu corpo se incrementaram quando eu descobri que era Deus. Mas acho que você não vai se importar muito com as modificações.

GALIANA - Verdade?

NEEMIAS - Verdade.

GALIANA - Você pode me mostrar?

NEEMIAS - Claro que posso. Estou ansioso por isso.

GALIANA - Oh. Que fascinante! Venha. Vamos para um local mais reservado.

(Vão para um lugar oculto aos olhos do público. Ouvem-se apenas as vozes dos dois)

NEEMIAS - É só desatar aqui...

GALIANA - Nossa! Isso é o...

NEEMIAS - Exatamente...

GALIANA - Nunca vi nada assim.

NEEMIAS - E ainda não viu nada...

GALIANA - Quer que eu ajude?

NEEMIAS - Não precisa. É que eu tenho que tirar com jeito para não machucar... pronto!

GALIANA - (Inquieta) Ah, meu deus!

NEEMIAS - Pode pegar agora.

GALIANA - (Admirada) Meu deus!

NEEMIAS - Meu amor...

GALIANA - (Num susto) Oh, meu deus! (Maliciosa) Sim, meu deus! (Suplicante) Por favor, meu deus! (Exultante) Isso, meu deus! (Louca de prazer) Ai, meu deus!!!

\section{criança}

Personagens:

DRICO

LINO

(Dois meninos entram. Um deles leva uma bola de futebol nas mãos.) DRICO - Lino.

(Lino não responde) 
DRICO - Lino, fala comigo.

LINO - O que é?

DRICO - Eu não acho que a gente perdeu o jogo por sua culpa.

LINO - Eu era o goleiro, Drico.

DRICO - Um goleiraço!

LINO - Dezoito a zero.

DRICO - Olhe aí!

LINO - Olhe aí o que? Dezoito a zero, Drico! Levei dezoito gols!

DRICO - E então? O nosso time não fez nenhum gol. A gente também jogou mal.

Ninguém tem direito de culpar você.

LINO - O goleiro deles era muito bom... Era ou não era?

DRICO - Não achei muito bom, não.

LINO - Claro que era! Eu estava vendo as defesas dele!

DRICO - Ah, Lino, deixa isso pra lá.

LINO - "Deixa isso pra lá", "deixa isso pra lá". Você é criança mesmo, hem?

DRICO - Você também é criança.

LINO - Eu não.

DRICO - É, sim. Quantos anos você tem? Oito?

LINO - Oito anos e dois meses. (Com orgulho) Quase nove.

DRICO - Criança como eu.

LINO - Você tem quantos?

DRICO - Vou fazer oito no mês que vem.

LINO - É mais criança do que eu.

DRICO - Sou não.

LINO - É, sim.

DRICO - Não sou.

LINO - (Num tom artificial de maturidade) Está bem. Não vou discutir com você.

DRICO - O que?

LINO - É isso mesmo.

DRICO - Isso mesmo, o que?

LINO - Meu pai que diz assim, quando as pessoas falam muita besteira na frente dele.

DRICO - As pessoas?

LINO - (Mesmo tom forçado) Não vou discutir com você, Drico. Já disse e não vou repetir.

DRICO - Você fica ridículo falando desse jeito.

LINO - (Ainda o mesmo tom forçado) Você é muito criança para entender.

DRICO - Para com isso, que saco.

LINO - Tá bom, já parei.

(Silêncio)

DRICO - Qual é o problema em ser criança?

LINO - Todos os problemas.

DRICO - Quais?

LINO - Criança torra a paciência de qualquer um.

DRICO - Adulto também torra.

LINO - É diferente. Só uma criança não entende. Criança enche o saco. Adulto sabe o que está fazendo. 
DRICO - Eu sei o que estou fazendo.

LINO - Sabe?

DRICO - Claro. Estou conversando com você.

LINO - Olha só a resposta dele.

DRICO - Mas eu estou conversando com você.

LINO - Para os adultos, sempre tem alguma coisa por trás do que parece que está acontecendo, entendeu?

DRICO - Não. Me explique.

LINO - Ta bom. É assim... éééé... as vezes... compreende, o que acontece é o seguinte, mais ou menos assim...

DRICO - Estou esperando.

LINO - Sabe o que é, Drico...

DRICO - Não.

LINO - Ah, nem adianta eu explicar porque você não vai entender.

DRICO - Explique. Pode ser que eu entenda.

LINO - Que nada, você é criança demais.

DRICO - E no que você é adulto? Hem? O que é que você faz que é tão adulto assim?

LINO - Eu já dirigi o automóvel do meu pai.

DRICO - Com você no colo dele, não vale. Escolha outra coisa.

LINO - Eu durmo tarde.

DRICO - Conte outra, que minha mãe disse que você dorme as vinte e uma horas.

LINO - Como é que ela sabe?

DRICO - Ela é amiga da sua mãe, ora. Ela vai na sua casa e vê que você está dormindo. Ela até usa isso pra me convencer a ir pra cama na mesma hora que você.

LINO - E você vai?

DRICO - Claro, né?

LINO - Que chato.

DRICO - Que chato, nada. Você não disse que era adulto? Adulto dorme a hora que quiser. Quem dorme com hora marcada é criança, viu, criancinha!

LINO - Criancinha uma porra. Eu já comi uma dona e você não comeu. Já comeu?

Comeu?

DRICO - Não! Não comi!

LINO - Eu comi. Quem é a criança, agora?

DRICO - Conversa. Quando foi isso?

LINO - Foi... foi... mês passado.

DRICO - E porque não me contou?

LINO - Assunto particular.

DRICO - É? E quem foi que você comeu?

LINO - A Leila, a filha da vizinha, aquela bem gostosa, assim, daquele jeito, gostoso.

DRICO - Que mentira, Lino.

LINO - Comi sim.

DRICO - Comeu nada.

LINO - Juro.

DRICO - Eu vou agora mesmo perguntar para ela.

LINO - Drico, se você fizer isso, eu deixo de ser seu amigo pra sempre!

DRICO - Então é mentira sua.

LINO - Não. O problema é que... éééééé... eu... eu... eu jurei para ela que nunca ia 
contar para ninguém. Só contei para você porque você é meu amigo.

DRICO - Pôxa, que legal, Lino.

LINO - Pois é.

DRICO - Vai, então, conte como foi que você comeu ela.

LINO - Comi comendo, ora.

DRICO - Eu sei, mas conte tudo, todos os pedacinhos da história.

LINO - Está bem... (Tenta de fazer suspense e.ao mesmo tempo, inventar algo "verossímil") Primeiro ela...

DRICO - Ela...

LINO - Ela... éééé... tirou as calças...

DRICO - Eita! Você viu a xoxota dela?

LINO - Claro que eu vi, né Drico!

DRICO - E como era? Como era?

LINO - Ééééé... era, assim...

DRICO - Era grande?

LINO - Era. Deste tamanho!

DRICO - Tinha pentelho?

LINO - Um monte!

DRICO - Fala mais, fala mais!

LINO - Ah, Drico, era igual a qualquer xoxota, que coisa. Quando você tiver a minha idade você vai ver direitinho como é que elas são.

DRICO - E você?

LINO - Eu o que?

DRICO - O que você fez quando ela mostrou a xoxota?

LINO - E aí eu... éééé ... eu tirei as calças e... e...

DRICO - E?

LINO - (Desatando a falar) E aí eu comi ela, comi, comi, comi, comi, assim, tudinho, assim, ao redor, em cima e em baixo, aí ela ficou gritando e fazendo, entende, porque eu fiquei ali, gozando bem muito, umas cinquenta vezes, com muitos espermatozóides saindo para todo o lado, cada um deste tamanho, saindo, saindo, a gente se abraçando bem forte e gritando muito, assim, aaaaaaaaai, uma loucura muito doida. DRICO - Doeu?

LINO - Você não sabe? Nunca viu nos filmes as caras que as pessoas fazem? Dói demais, velho! Mas também é muito gostoso.

DRICO - Sai sangue?

LINO - Um pouquinho.

DRICO - Você teve medo?

LINO - Eu sou macho, porra!

DRICO - Eu sei, mas, você teve medo?

LINO - Você faz cada pergunta de criança, Drico. Foi tudo bom demais, pronto!

(Drico fica olhando em silêncio, chocado, tentando assimilar as informações, enquan-

to Lino sorri, vitorioso. Sério, imóvel, Drico finalmente faz um comentário)

DRICO - Você jura que isso tudo que você contou aconteceu de verdade?

LINO - Você ainda não está acreditando?

DRICO - É que eu acho que ninguém goza cinquenta vezes.

LINO - Como é que você sabe, se você é criança e nunca comeu ninguém?

DRICO - Já ouvi meu primo falando que o máximo que um homem goza são dez 
vezes por dia.

LINO - Aquele seu primo não sabe de nada.

DRICO - Sabe sim. Ele tem namorada, ouviu? Já chupou o peito dela e tudo.

LINO - Ele disse isso?

DRICO - Disse nada. Eu vi acontecendo! Vi tudo. Pelo buraco da fechadura.

LINO - (Frenético, curioso) Viu o que? O que? O que?

DRICO - Ele, com o bocão lá, nos peitos da outra, babando tudo isso aqui (mostrando a região do próprio peito) nela.

LINO - Jura?

DRICO - E então, estou dizendo! Não vi tudo tudo, mesmo, mas deu pra ver daqui pra cima (faz o gesto mostrando da cintura para cima). Ela ficava revirando os olhos, assim, como se fosse desmaiar, se alisando, pegando nos cabelos, alisando meu primo, a maior agonia. Meu primo suava, respirando forte, soprando, como estivesse com asma, se esfregando e lambendo aqueles peitos e ela toda ai... ai... ai. Devia ser essa dor que você falou, que já estava começando. Sabe que naquela hora começou a me dar a maior vontade de fazer também?

LINO - Eu sei. Era isso que eu estava querendo Ihe explicar. Mas e aí? E aí? Conte o resto.

DRICO - Eles começaram a pirar, meu irmão. Teve uma hora que ele se deitou ali em cima e ficou, se remexendo todo. Ela ficava dizendo "vai logo, vai logo".

LINO - E era para ir para onde?

DRICO - Não sei, eu não entendi. Devia ser algo que eles iam fazer depois.

LINO - E aí?

DRICO - Ela dizia "vai logo, vai logo" e aí ele falava "calma, ai meu Deus, é agora" e aí ela mudava de idéia e ficava "espere por mim, espere por mim". Nessa hora ele parava de se remexer e os dois ficavam quietinhos, rindo, quiquiqui, cacacá.

LINO - Acho que eles beberam.

DRICO - Eu também.

LINO - Quem bebe é que fica falando bobagem.

DRICO - É. Aí eles falavam essas doideiras e depois começavam tudo de novo, dizendo as mesmas coisas: "vai", "vem", "é agora" e "espera por mim".

LINO - E como foi que acabou? Eles gritaram muito?

DRICO - Não podiam gritar. A casa toda ia escutar. Acho que eles fizeram tanto esforço para prender os gritos que, no final, passaram um tempão se tremendo, o corpo fazendo assim, como se estivessem com soluço, os dois soprando e gemendo, fuuuu, fuuuu. Depois se calaram. Pensei até que tivessem morrido. Aí começaram a se mexer, olharam um para a cara do outro e começaram a risadagem outra vez.

LINO - Doideira, velho.

DRICO - Só! O melhor de tudo é quando eles se levantaram, sabe o que aconteceu?

LINO - O que? O que?

DRICO - Eu vi a xoxota da namorada dele.

LINO - Viu?

DRICO - Todinha, virada pra mim, bem pertinho.

LINO - Era grande?

DRICO - Enorme. Tão cabeluda. Eu podia jurar que aquela xoxota estava viva, sorrindo pra mim, assim, ó, jogando charme. Eu fiquei tão bobo que quase dei adeus pra ela, atrás da porta, vê se pode. Parece piração minha, mas eu fiquei com a maior 
impressão de que aquela xoxota sabia mesmo que eu estava olhando pela fechadura... e tem mais: ela estava adorando que eu olhasse para ela.

LINO - (Fascinado) Pôxa! Eu queria ter visto também.

DRICO - Foi incrível. Quando minha mãe me levar na casa do meu primo, eu chamo você. Só não garanto ver alguma coisa. Vai depender da namorada dele aparecer por lá.

LINO - Tá.

(Silêncio)

DRICO - Você não comeu mesmo a Leila, comeu?

LINO - Comi.

DRICO - Fala a verdade, Lino.

LINO - Tá bom. Comi, mas só gozei nove vezes.

(Silêncio)

DRICO - A sua vida mudou muito depois que você comeu sua primeira mulher?

LINO - Totalmente. Sou outra pessoa.

DRICO - Parece o mesmo Lino de sempre.

LINO - Sou menos criança.

DRICO - E aí? É bom?

LINO - Muito bom.

DRICO - Como é que eu faço para comer uma dona?

LINO - Você é muito criança, mesmo.

DRICO - (Dando empurrões em Lino, enquanto fala) Você pare de me chamar de criança, porra! Não agüento mais! Você fala, parece que eu sou algum lixo. Você não é melhor do que eu em nada, tá me ouvindo? Seu porra!

LINO - Calma, meu filho, calma.

DRICO - Eu não sou seu filho. Eu tenho nome. Você é meu amigo. Não devia me tratar como se eu fosse um monte de merda. Peça desculpas ou então eu vou embora e não falo nunca mais com você.

LINO - Desculpa?

(Pausa. Clima.)

(Silêncio. Tensão)

DRICO - Tá... Desculpo.

(Silêncio)

DRICO - Por que você acha tão ruim ser criança?

LINO - Eu acho que quando a gente é adulto, ninguém grita com a gente. A gente é livre. Faz o que quer, a hora que quer. Quando a gente é adulto, a gente não tem obrigação de fazer dever de casa, de ir pra escola. A gente pode entrar num carro bem grande, ligar ele e sair correndo bem muito, para bem longe, até chegar na Disney World. A gente pode fazer tudo sem pedir pra ninguém. Quando a pessoa é adulta, todo mundo respeita ela.

DRICO - Você não sai muito daqui do prédio, não é?

LINO - Eu saio. Vou pra praia, pro shopping, pra casa de campo. Por que?

DRICO - Vida de adulto também não é muito boa. Tem o pessoal que não tem onde morar, que passa fome, tem a violência.

LINO - A violência é coisa de televisão. É de mentira. Eu vi como eles fazem. É igual ao cinema.

DRICO - Minha tia mora juntinho de uma favela. No dia em que vi meu primo chupan- 
do o peito da namorada, a vizinha da minha tia foi morta, no meio da rua.

LINO - De verdade?

DRICO - De verdade. O traficante deu um tiro nela porque ela não quis dizer onde o filho dela tinha se escondido. O filho dela era traficante também.

LINO - O que é traficante?

DRICO - Deve ser alguma coisa muito ruim, feito morte, câncer, aids, essas palavras que as pessoas falam e fazem uma careta com medo do que estão dizendo.

LINO - Era muito feio? Ela morta?

DRICO - Era, sim. Eu fecho os olhos e ainda a vejo a dona, lá, deitada, com um buraco roxo, bem aqui (aponta para a própria testa), a cabeça numa poça de sangue, os olhos abertos, olhando pra rua. Veio um homem, cobriu com um lençol e mandou a gente ir pra casa.

LINO - A mulher morta, ela era muito velha? Assim, como a minha mãe?

DRICO - Era grande, velha, trabalhava, tinha filhos, casa. Não adiantou nada ser adulta. LINO - Meu pai, quando os amigos dele perguntam quantos filhos ele tem, ele diz: tenho uma menina e dois homens! Ele me chama de homem, Drico, e homem é adulto. Papai quer que eu seja um adulto. Ele precisa que eu seja um adulto. Não sei porque, mas ele precisa.

DRICO - Será que isso é algum teste que os adultos fazem para saber se nós estamos preparados para alguma coisa?

LINO - Um teste? Nunca pensei nisso.

DRICO - Adulto gosta de ficar testando a gente, não é?

LINO - Sim, deve ser isso! Falam essas coisas como se fosse besteira, mas vai ver que estão querendo que a gente descubra o grande segredo dos adultos.

DRICO - Legal.

LINO - Você faz idéia do que eles querem que a gente descubra?

DRICO - Nenhuma.

LINO - Se você descobrir alguma coisa, você me conta?

(Drico acena afirmativamente. Silêncio. Olham para o sol, quase que ao mesmo tempo)

DRICO - Eita, que horas são?

LINO - Sei lá. Já deve estar na hora do Samurai Ranger. Vamos entrar?

DRICO - Vamos.

(Saindo)

LINO - Você assistiu na semana passada?

DRICO - Assisti. Viu quando ele derrotou os monstros de cera da estrela dourada?

LINO - Radical, velho.

DRICO - Achei irada aquela cena dele cortando a cabeça de quatro monstros com um mesmo golpe de espada... zim!

(Saem, simulando uma luta entre seus personagens favoritos)

\section{transbordamento}

Personagens: 
GUARDA 1

GUARDA 2

(Dois personagens usando uniformes, como vigilantes estilizados, se revezam marchando para lá e para cá, tomando conta de uma enorme represa imaginária. Carregam como armas coisas como martelos gigantes de plástico e grandes matadores de moscas. Antes de chegarem no local da peça, podem circular batendo latas num ritmo parecido com o das La Ursas, enquanto cantarolam algo que lembre a melodia de hinos nacionais de países que tiveram - ou tem - influência no que ocorre hoje no Brasil, como Portugal, Espanha, França, Inglaterra e Estados Unidos. A única palavra que pronunciariam nesse passeio jocoso seria um uníssono "Za-Zil", emitido de vez em quando, como um grito de torcida de futebol. Ao chegarem na "base" da represa, local onde farão a ronda, encontrarão dois outros companheiros trajados de modo idêntico. Estes darão continência e se retirarão. Os recém-chegados "examinarão" a represa, surpresos, e farão comentários sobre o que vêem).

GUARDA 1 - É enorme.

GUARDA 2 - Maior do que eu imaginava.

GUARDA 1 - É a sua primeira vez na ronda?

GUARDA 2 - Primeira.

GUARDA 1 - Pois é. Olhando de longe a gente nem imagina.

GUARDA 2 - De longe a gente até esquece que existe.

(Silêncio. Suspense)

GUARDA 1 - Companheiro?

GUARDA 2 - O que é?

GUARDA 1 - Olhando assim, de pertinho...

GUARDA 2 - O que é que tem?

GUARDA 1 - Parece que a qualquer momento vai cair em cima da gente.

GUARDA 2 - Talvez caia.

GUARDA 1 - Nem diga uma coisa destas. Se bem que, na verdade, é para isso que estamos aqui.

GUARDA 2 - Prevenir deformações, detectar anormalidades e dar o alarme em caso de... de...

GUARDA 1 - Transbordamento.

GUARDA 2 - Isso mesmo.

GUARDA 1 - Você não disse a palavra porque esqueceu ou porque é supersticioso?

GUARDA 2 - Qual palavra?

GUARDA 1 - Transbordamento.

GUARDA 2 - Eu esqueci a palavra. Por isso não falei.

GUARDA 1 - Não foi por medo?

GUARDA 2 - Não. Não tenho medo de palavras.

GUARDA 1 - Transbordamento!

(Ao ouvir a palavra, o Guarda 2 tem uma rápida reação)

GUARDA 1 - Olhe aí! Você acabou de fazer uma careta quando eu a pronunciei novamente.

GUARDA 2 - Assim não vale. Você me pegou de surpresa. 
GUARDA 1 - (Rápido, num crescendo ameaçador) Transbordamento, transbordamento, transbordamento.

GUARDA 2 - (Desesperado, sem saber se corre, se anda, se pula, se grita) Pare de falar isso pelo amor de Deus!

GUARDA 1 - (Divertindo-se) Parei, parei, parei!

GUARDA 2 - (Tentando recompor-se) Não faça isso nunca mais. Se eu perder o controle poderei me tornar uma ameaça à sua integridade física.

GUARDA 1 - Desculpe. Eu não resisti. O pessoal de lá da empresa sabe que você é supersticioso?

GUARDA 2 - Não sabe e nem vai saber, porque você vai ficar caladinho, entendeu?

(Ouve-se um estalo no alto da represa. Os dois olham para cima, a postos)

GUARDA 2 - Você ouviu?

GUARDA 1 - Ouvi.

GUARDA 2 - O que terá sido?

GUARDA 1 - Não tenho certeza. Tanto pode ser uma acomodação de tensões ou uma exaltação de ânimos. Estou em dúvida.

GUARDA 2 - Se for uma acomodação de tensões, tudo bem, mas, e se for uma exaltação de ânimos?

GUARDA 1 - De novo, de novo, de novo.

GUARDA 2 - O que é isso?

GUARDA 1 - Estou mentalizando para ver se faz aquele barulho de novo e eu possa analisá-lo melhor. De novo, de novo...

GUARDA 2 - Pare com isso! Você pode estar energizando a coisa toda, dando força para a exaltação de ânimos!

GUARDA 1 - Eu só quero ter certeza do que foi aquele barulho.

(Ouve-se outro barulho totalmente diferente)

GUARDA 2 - E esse?

GUARDA 1 - Tão fácil. Você não sabe? Devia ter estudado melhor o programa diagnóstico de Transbordamento.

(Ouve-se novo barulho. Os dois olham para cima)

GUARDA 2 - O que é aquilo aparecendo?

GUARDA 1 - Um galho de árvore.

GUARDA 2 - Não seriam chifres?

GUARDA 1 - Daquele tamanho?

GUARDA 2 - Bom, galhos não ficam se movendo para lá e para cá.

GUARDA 1 - De fato. Nunca se sabe o que pode surgir vindo daquele mundo.

GUARDA 2 - Sumiu. Não é melhor dar o alarme?

GUARDA 1 - Que nada. É comum a gente ver a ponta de uma coisa, um pedaço de outra. Aparece e fica nisso mesmo.

GUARDA 2 - Sei não.

GUARDA 1 - Relaxe. Um chifrezinho aparecendo de vez em quando não faz mal a ninguém.

GUARDA 2 - Mas e se isso for o prenúncio de um...

GUARDA 1 - Transbordamento? De chifres? Qualquer país pode conviver com isso.

(Sons de metralhadoras)

GUARDA 2 - E agora? É melhor dar o alarme!

GUARDA 1 - Calma! Você nunca ouviu esse barulho antes? É o mais óbvio de todos 
os ruídos que estudamos antes de vir para cá.

GUARDA 2 - Ouvi, sim. Precisamos fazer alguma coisa.

GUARDA 1 - Precisamos nada. O barulho foi do lado de lá. Problema seria se transbordasse e o barulho viesse para o lado de cá.

GUARDA 2 - E se o negócio...?

GUARDA 1 - Transbordar? Amigo, faz séculos que isso ameaça transbordar e não transborda. As pessoas pesquisam, escrevem livros, falam o tempo todo desse transbordamento, mas é só olhar e ver que tudo isso aí nunca vai mudar mesmo. Pode acreditar.

(Enquanto Guarda 1 relaxa, Guarda 2 examina atentamente o alto da represa)

GUARDA 2 - (Tomando um susto) Ai!

GUARDA 1 - O que foi?

GUARDA 2 - O que é aquilo mole, aparecendo ali?

GUARDA 1 - Mole? Onde.

GUARDA 2 - Ali! Ali, olhe! Aquilo balançando, tremendo todo!

GUARDA 1 - Não estou vendo nada.

GUARDA 2 - Meu Deus! Está se mexendo para lá e para cá! Não é possível que você não esteja vendo!

GUARDA 1 - Ei, camarada, um minuto.

GUARDA 2 - Temos que dar o alarme!

GUARDA 1 - Amigo! Tenha calma.

GUARDA 2 - Olhe! Ainda está lá!

GUARDA 1 - Amigo, por favor.

GUARDA 2 - É um alienígena!

GUARDA 1 - Isso não existe!

GUARDA 2 - (Num desespero cada vez maior) Claro que existe! Estou vendo e não estou sob o efeito de nenhuma droga! Olhe lá! Pelo amor de Deus, não é possível que você não esteja vendo! Se essas criaturas asquerosas começarem a transbordar para cá estaremos perdidos.

GUARDA 1 - (Enérgico) Amigo! Chega! (Estapeando o Guarda 2, que não para de falar) Me escute!

GUARDA 2 - (Atordoado) O que foi?

GUARDA 1 - (Tira uma remela que estava pendurada nos cílios do Guarda 2) O problema não era lá em cima. Era essa remela pendurada nos seus cílios.

(O Guarda 2 tenta se acalmar, arfante)

GUARDA 2 - Sai de casa sem lavar o rosto.

GUARDA 1 - Ô, companheiro, você fez mesmo o treinamento para estar aqui, nesta ronda?

GUARDA 2 - Não. Entrei aqui sem concurso. Dá para perceber o meu despreparo?

GUARDA 1 - Um pouco. De quem você é parente?

GUARDA 2 - Sou genro do cunhado do irmão da tia da noiva do avô da amante do secretário do chefe de gabinete do segundo presidente da empresa.

GUARDA 1 - Ah, bom. Aí está certo.

GUARDA 2 - Você me compreende?

GUARDA 1 - Claro. Sou neto do vizinho da sobrinha da irmã do concunhado da tia-avó da dentista do comandante da filial norte da empresa. 
GUARDA 2 - Que maravilha! Muito prazer.

GUARDA 1 - Devia ter me dito logo. Ao invés de lhe tratar como um expert, eu lhe ensinaria tudo sobre este trabalho para você, assim como o meu ex-colega de ronda me ensinou há dois meses.

GUARDA 2 - Vou ficar lhe devendo um imenso favor.

GUARDA 1 - Vai sim. Captou bem o espírito da idéia.

GUARDA 2 - Que ótimo.

GUARDA 1 - A primeira vez que eu vim aqui, eu não sabia de nada. Meu ex-colega me ensinou tudo. É sempre assim. Um ciclo vicioso onde a gente vai dando a mão um pro outro e levando as coisas pra frente.

GUARDA 2 - Fantástico. E este seu antigo colega, onde está?

GUARDA 1 - Infelizmente faleceu.

GUARDA 2 - Que pena.

GUARDA 1 - Transbordaram umas coisas na cabeça dele.

GUARDA 2 - Como foi isso?

GUARDA 1 - Transbordando. Ele estava bem aí, onde você está. O chão tremeu e aí ele...

GUARDA 2 - Morreu.

GUARDA 1 - Saiu correndo. A coisa toda transbordou ali na frente.

GUARDA 2 - Ele morreu ali?

GUARDA 1 - Não, dali ele foi pro hospital, coitado.

GUARDA 2 - Morreu no hospital?

GUARDA 1 - Não. Morreu em casa. Os médicos que o operaram esqueceram uma agenda na barriga dele.

GUARDA 2 - Morreu de infecção?

GUARDA 1 - Não. De raiva. A agenda era dele. A vida dele estava toda ali. Desorganizou-se todo. Coisa horrível.

GUARDA 2 - Lamento muito. E o ... o ...

GUARDA 1 - O transbordamento...

GUARDA 2 - Sim. Aquele que o matou.

GUARDA 1 - Foi contido. Assim, ó.

(Pega o martelo de borracha e sai batendo na cabeça das pessoas que estão assistindo a peça. Ouve-se uma sirene)

GUARDA 2 - E agora?

GUARDA 1 - Hora do cafezinho. Vamos ali tomar um expresso?

GUARDA 2 - E a ronda?

GUARDA 1 - Serão só quinze minutos. Esse negócio não transbordou até agora, não vai transbordar porque a gente foi tomar uma coisinha ali na esquina.

GUARDA 2 - Companheiro, você é uma figura e tanto.

GUARDA 1 - Eu sei.

(Saem como entraram, batendo latas)

\section{códigos}

Personagens: 


\section{Soldado 1402 \\ Soldado 2894 \\ Soldado BSPX \\ Soldado JLTT}

(Duas trincheiras numa guerra. Bonecos com caras não-realistas - como se fossem bruxas de pano, dessas que vemos nas feiras do interior estão jogados no chão simulando mortos e feridos. Em cada uma das trincheiras estão dois soldados 1402, 2894, BSPX e JLTT, sendo que a platéia não vê claramente BSPX e JLTT, que estão ocultos em uma delas. Saraivadas de balas e bombas. Na que fica mais próxima e à mostra da platéia, o soldado 1403 fala com o quartel general através de um celular) 1402 - Soldados 1402 e 2894 do grupamento pat-arrôba-flax-ponto P sob ataque intenso. Apenas dois sobreviventes em nossa trincheira. Desconhecemos a situação nos outros postos. Precisamos de reforços. Repito: precisamos de reforços. Estão me ouvindo? (Pausa) Alô? Alô? (Para 2894) Caiu a linha.

1402 - Parou?

(O ataque cessa. 1402 e 2894 ficam surpresos)

2894 - Parece.

(Tensão)

1402 - Não devíamos dar uma espiada?

2894 - Estou com medo de levar um tiro.

1402 - Eu também.

2894 - Mesmo assim, é preciso olhar. Se não olharmos, estaremos infringindo o nosso Código.

1402 - Capítulo 10, artigo 9, delito de covardia.

2894 - Então é melhor você olhar.

1402 - Eu?

2894 - Sim, senão vai para a Corte Marcial.

1402 - Ah, é, engraçadinho? E por que você não olha? Temos a mesma patente.

2894 - Por que eu sou mais jovem que você.

1402 - Um ano, se tanto.

2894 - Não importa. Em tese, terei mais tempo que você para oferecer uma contri-

buição ao mundo. Minha vida deve ser preservada prioritariamente. A sua é mais sacrificável que a minha.

1402 - Isso está em que código?

2894 - No da lógica.

1402 - Pelo código da lógica, pessoas com mais idade experimentaram mais situações adversas e, portanto, estão mais preparadas para oferecerem soluções para os problemas do mundo. Sacrificável é você.

2894 - (Rindo sem graça) Então empatou, né?

1402 - É.

2894 - Mas o que vamos fazer, então?

1402 - Estou pensando. Se você se calar um pouco talvez eu ache uma solução.

2894 - Ta bom. Tem razão.

(Silêncio)

2894 - (Súbito) Os dois ao mesmo tempo! 
1402 - Que susto! Está louco!

2894 - Os dois! Eu e você!

1402 - Como é? Não estou entendendo?

2894 - Devemos olhar os dois ao mesmo tempo.

1402 - Olhar, como?

2894 - Olhando. Levantando a cabeça e olhando.

1402 - Ao mesmo tempo?

2894 - Ao mesmo tempo.

1402 - Arriscando-nos a morrer os dois ao mesmo tempo.

2894 - Sim. Se você não quer se arriscar e eu também não...

1402 - Que código é esse?

2894 - O do desespero.

1402 - Ainda não estou tão desesperado assim. Deve haver outro modo.

2894 - Ai, meu Deus.

1402 - Silêncio, me deixe pensar. E não me dê outro susto como o que você me deu há pouco.

2894 - Claro que não, foi mal, desculpe.

(Silêncio, tensão. 2894 fica inquieto, tentando criar coragem para olhar além da trincheira)

2894 - (Falando baixo, com cuidado) Ai, meu Deus. Ai, meu Deus. (Para 1402) Licen-

ça. Posso falar? (Sem esperar resposta) Já que estamos demorando para resolver o que fazer, é possível que eles estejam se aproximando para verificar se restou algum de nós.

1402 - (Pensa um pouco e se preocupa) Tem razão. Podem estar fazendo isso neste exato momento.

2894 - Ou não, mas...

(Olham-se, muito preocupados)

1402 e 2894 - Precisamos olhar.

1402 - Que tal um par ou ímpar?

2894 - Pode ser. Vamos lá. Par ou ímpar?

1402 - Par.

2894 - Ímpar. Uma, duas, três e já...

(Jogam as mãos)

1402 - Sete é ímpar, ganhei.

2894 - Então você olha.

1402 - Eu não. Eu ganhei.

2894 - Ganhou o direito de olhar.

1402 - Ganhei o direito de olhar você olhar.

2894 - Nada disso.

1402 - Mas, que coisa, onde raios você aprendeu a jogar par ou ímpar? Na minha terra quem ganha sempre fica com a melhor parte.

2894 - Na minha também. Você ficou com a melhor parte. Vai ser um herói e salvar a minha vida.

1402 - Dispenso essa honra. Que tal você ser meu herói?

2894 - Não levo jeito.

1402 - (Pegando uma moeda) Então vamos tirar no cara ou coroa.

2894 - Ótimo! O meu é cara! 
1402 - O meu é coroa.

2894 - Quem perder olha, ouviu?

1402 - Quem perder, olha, certo.

(1402 atira a moeda para cima. Dá cara.)

2894 - Cara! Issa! Ganhei! Está vendo? É o destino. Você olha! Você olha!

1402 - Nada disso. Código da Justiça Lúdica. Tenho direito a ter as mesmas chances que você. Você não se livrou no par ou ímpar? Eu quero me livrar dessa. A gente zera o placar e, a partir de agora, quem perder olha de uma vez e pronto.

2894 - Ta bom. Mas eu jogo a moeda.

1402 - Não senhor. Não confio em você.

2894 - Nem eu em você. Já não jogou uma vez? Agora eu jogo. Justiça lúdica.

1402 - (Passando a moeda) Tome. Jogue logo esta merda. E o meu é coroa!

2894 - Coroa é o meu.

1402 - Eu falei primeiro.

2894 - Cara, pronto.

(2894 joga a moeda e dá cara.)

2894 - (Cantando, comemorando baixinho) Ganhei, ganhei, ganhei.

(Furioso, 1402 olha para 2894 e começa a se preparar. Respira fundo, enquanto 2894 continua a cantar)

2894 - Obrigado senhor, obrigado, porque eu ganhei, ganhei, ganhei. Obrigado, obrigado, pelas graças que me deste, ganhei, ganhei, ganhei...

1402 - Companheiro, eu vou olhar, mas pare com essa musiquinha senão eu vou te encher de porrada.

2894 - Parei.

(1402 cautelosamente olha. Alguém atira, mas ele se recolhe à tempo)

2894 - E aí? E aí?

(1402 não responde. Começa a arrumar suas coisas na mochila)

2894 - 1402? O que foi que você viu?

1402 - (Fazendo suspense, abre um sorriso maldoso) Não digo!

2894 - O que?

1402 - É isso aí. Se quiser, olhe você! (Continua a arrumar suas coisa na mochila)

2894 - Por que está arrumando suas coisas?

1402 - (Irônico) Porque.

2894 - É assim, é?

(1402 não responde)

2894 - Eu arrumo as minhas também. (Começa a arrumar a própria mochila)

1402 - Vai ficar me imitando? Pode se dar mal. Você não sabe o plano que eu tenho na cabeça.

2894 - Isso não é conduta de um soldado digno.

1402 - Esse julgamento é baseado no seu código pessoal, não no meu, engraçadinho. Já não bastou eu ter vindo parar nessa guerra, ainda tenho que suportar você querendo me fazer de besta. Quer saber o que eu vi? Nada! Coisa nenhuma! Eles continuam atentos, mas ninguém saiu da trincheira. E sabe o que vou fazer agora? (Pega o celular e digita) Vou tentar falar com o QG e pedir autorização para recuar. Satisfeito? Idiota.

2894 - Pôxa, companheiro, sinceramente, peço-lhe mil desculpas. Você nunca sinalizou que era tão sensível. Se eu soubesse... 
1402 - (Para si, enquanto ouve os sons de chamada do celular) Atende, porra.

(Ouve-se aquela voz chata da telefonista dizendo que caiu na caixa pos-

tal. Quando ouve o sinal, 1402 deixa o recado)

1402 - Se eu morrer aqui, vocês me pagam, seus filhos da puta!

2894 - Enlouqueceu?

1402 - Quase.

2894 - E agora?

1402 - Vou fugir.

2894 - Vai levar um tiro.

1402 - Talvez... (Começa a ter uma idéia) A não ser que... (Olha para um fuzil e o pega) Arrume uma camisa, um lenço, um tecido branco. Vamos nos entregar.

2894 - Verdade! Podemos nos entregar! Essa hipótese era tão simples e óbvia que nem havia me passado pela cabeça. Claro! Claro.

(Procuram e encontram um pano branco manchado de vermelho)

1402 - Está meio sujo de sangue, mas acho que dá para demonstrar a intenção.

2894 - Claro que sim.

(Amarram o pano no fuzil e o erguem. Nenhum tiro. 1402 e 2894 se levantam com as mãos para o alto.)

1402 - Deu certo.

(Ouve-se a voz de BSPX oculto na outra trincheira)

BSPX - Agora!

(Tiros. 1402 e 2894 caem mortos. Os dois soldados da outra trincheira levantam-se cautelosos e aproximam-se dos corpos recém abatidos)

BSPX - Você é extraordinário, JLTT. Conhece bem os adversários.

JLTT - Tenho sensibilidade acurada. Consigo captar todos os códigos com muita facilidade.

BSPX - Me explique o que aconteceu aqui, então.

JLTT - Fácil. Primeiro o fuzil erguido. Ora, ele apontava para o céu, onde não havia nenhum oponente. Isso significava que a munição de fato havia acabado. $O$ tecido branco todo manchado de sangue dizia claramente: "rendição, nem pensar". Ao sairem da trincheira tranquilos, como quem vai dar uma caminhada no quintal de casa, já indicavam que nada mais tinham a perder. Enfim, quando ergueram os braços para cima, numa clara atitude de ataque, mostraram que estavam dispostos a lutar conosco, com as próprias mãos, até a morte.

BSPX - Quanta coragem.

JLTT - Grandes adversários.

BSPX - Felizmente somos civilizados o bastante e pudemos garantir-lhes uma morte rápida e honrosa.

JLTT - Pois é, caro BSPX. Uma sociedade sólida como a nossa deve ser capaz de tais gestos de grandeza mesmo nos estertores da guerra.

(Saem) 


\section{dissolução}

Personagens:

JUIZ

HOMEM 1

HOMEM 2

Placa indicativa: "Em algum lugar de um futuro próximo"

JUIZ - Dissolução promocional! Dissolução promocional! Cinquenta por cento de desconto em qualquer tipo de dissolução! É isso mesmo amigos! Aproveite! Somente hoje, aqui, no Disk Law! Olha o Disk Law! Disk law! É delivery, gente! Você não precisa sair de casa: digite em qualquer módulo conectivo "éle", "a", "dâbliu" e o tribunal a domicílio vai até você! Disk Law! Serviço 48 horas por dia, com acesso gratuito pela rede telepática mundial! Conecte sua mente conosco imediatamente e resolva suas pendengas jurídicas sem complicação! Habeas corpus, acusação, condenação, absolvição, com ou sem apelação, tudo fácil e descomplicado para melhor servir a você. Aproveite a nossa promoção especial com cinquenta por cento de desconto para toda e qualquer dissolução!

(Entram dois homens elegantes, de mãos dadas - as mãos não se largam nem um momento da trama)

HOMEM 1 - (Levantando a mão que segura a do companheiro) Dissolva isto pelo amor de Deus, excelência. Agora, já, imediatamente.

JUIZ - Uau-auau! Um divórcio homossexual! Que coisa tão legal! Isso é sempre muito contemporâneo!

HOMEM 2 - O nosso problema não é a homossexualidade.

JUIZ - Percebe-se que não é. A convivência é que é difícil.

HOMEM 1 - O senhor não entendeu.

HOMEM 2 - O nosso único vínculo é político.

HOMEM 1 - Justamente.

JUIZ - Homopolíticos?

HOMEM 1 - Nem isso.

HOMEM 2 - Heteropolíticos até a alma.

JUIZ - E por que resolveram se casar?

HOMEM 2 - Por causa das eleições.

JUIZ - Não compreendo.

HOMEM 2 - Fizemos este casamento por conveniência porque era interessante mostrar para os eleitores que éramos o que, na verdade, não éramos.

HOMEM 1 - Eu tinha a popularidade.

HOMEM 2 - E eu tinha o dinheiro, a influência política nas altas esferas.

HOMEM 1 - Separados, pouco conseguiríamos.

HOMEM 2 - Mas, juntos.

HOMEM 1 e 2 - Aaaaah, juntos!

JUIZ - Ah, sim. E ganharam a eleição.

HOMEM 1 - Ganhamos. Eu sou vereador e ele é deputado federal.

JUIZ - Ah, vocês formam um casal tão bonito, não deviam se separar. 
HOMEM 2 - Está vendo? O juiz também acha.

JUIZ - Acho o que?

HOMEM 1 - (Para o Juiz) Ele não quer dissolver nossa coligação. Acha que está tudo indo muito bem assim.

HOMEM 2 - Nunca fui tão feliz.

HOMEM 1 - Você é muito egoísta. Nunca parou para me perguntar como eu me sentia nisso tudo.

HOMEM 2 - Não seja injusto. Jamais neguei um pedido seu.

HOMEM 1 - Não falo de bens materiais. Falo de como me sinto por dentro, com meus antigos colegas de luta me encontrando na rua e virando a cara para mim, como se eu fosse... como se eu fosse... (começa a chorar).

HOMEM 2 - (Abraça o Homem 1) Não chore. Tudo vai terminar bem.

HOMEM 1 - (Choramingando) A minha dignidade está despedaçada. Não sei se valeu a pena trocá-la por um cargo na política. Eu preferia a vida de militância, acusando um oponente aqui, reclamando de outro ali, organizando passeatas, fazendo campanha nas comunidades. Isso é que era vida. Hoje, não. É esse marasmo, essa coisa igual o tempo todo, esses jantares, essas mordomias, viagens, eventos que não vão e nem vêm, sem falar nessas infinitas e abomináveis filas de gente me pedindo um monte de coisas como se eu fosse pai delas.

HOMEM 2 - Eu nunca Ihe pedi nada. Tudo o que eu quero é ter você perto de mim. HOMEM 1 - Você não diz isso de coração. É o seu bolso quem está falando.

HOMEM 2 - Não seja tão cruel consigo mesmo. Ainda podemos ser muito felizes. Outras eleições virão.

HOMEM 1 - Você é que é feliz. Ninguém nem se lembra mais dos seus desvios de dinheiro, das suas mentiras. Mas, nos meios intelectuais, todos enchem a boca para me chamar de traidor da causa.

HOMEM 2 - Você dissolveu o ódio que as pessoas tinham de mim.

HOMEM 1 - (Para o juiz) Foi ele quem deixou aquele rombo de 12 milhões na previdência social e nunca devolveu o dinheiro.

JUIZ - Foi o senhor?

HOMEM 2 - Foi.

JUIZ - Eu vi seu julgamento na televisão! Olhe, o senhor está ótimo sem aquele bigode horroroso. Irreconhecível!

HOMEM 2 - Sugestão dele (apontando para o Homem 2). Disse que ajudaria a fazer as pessoas se esquecerem dos meus problemas de cleptomania crônica. É um homem brilhante, pois foi exatamente o que aconteceu.

JUIZ - Que maravilha.

HOMEM 1 - Vê? Ele resolveu tudo na vida dele. E eu? O que é que estou ganhando com isso?

HOMEM 2 - Mídia. Estou investindo uma nota para vender sua imagem como o ídolo do amanhã. Um dia você vai ser presidente do mundo e eu vou ser o seu vice.

HOMEM 1 - Dissolva esse negócio agora mesmo, excelência.

JUIZ - Você não quer ser presidente?

HOMEM 1 - Querer até que eu quero, excelência. Mas não dá mais para viver coligado.

JUIZ - Permita-me dizer que você chora de barriga cheia, meu filho. Adoraria estar no seu lugar. 
HOMEM 1 - Não adoraria não, excelência.

HOMEM 2 - Não invente de dizer aquilo.

HOMEM 1 - Vou dizer sim.

HOMEM 2 - Isso não é justo.

HOMEM 1 - O que é que eu posso fazer?

HOMEM 2 - Tudo, mas isso, não, por favor.

HOMEM 1 - Então facilite as coisas e aceite a dissolução.

HOMEM 2 - Você jurou que não usaria isso para me pressionar.

HOMEM 1 - Eu não tenho outra alternativa.

HOMEM 2 - Você é um ingrato.

HOMEM 1 - Não suporto mais viver assim.

HOMEM 2 - Pois se você abrir a sua boca para dizer uma palavra sobre...

JUIZ - Se ameaçá-lo, mandarei prendê-lo.

HOMEM 2 - Eu tenho dinheiro. Pago qualquer coisa para você ficar calado.

HOMEM 1 - Não! Eu vou falar! Eu vou falar!

JUIZ - Fale logo de uma vez que estou morrendo de curiosidade!

HOMEM 2 - Não!

HOMEM 1 - Ele ronca a noite toda, tem mau hálito e faz xixi na cama. Pronto. Eu disse. Agora dissolva esta farsa de uma vez.

HOMEM 2 - Não, não, não, não. Por favor. Por favor!

HOMEM 1 - Vamos logo com isso, excelência. Tenha piedade.

(O Juiz acena com a cabeça e começa a fazer uma série de gestos ritualísticos)

HOMEM 2 - Não, não, não! Ai, por favor, eu imploro!

JUIZ - Separati sumus!

(As mãos dos dois se soltam.)

JUIZ - Pronto. Coligação dissolvida.

HOMEM 2 - Para sempre?

HOMEM 1 - No que depender de mim...

(Homem 2, incrédulo, olha suplicante para o Juiz)

JUIZ - (Apontando para o Homem 1) No que depender dele...

(O Homem 2 fica em suspenso, tentando crer no que se passa, enquanto

o Homem 1 se dá conta do prazer de estar livre e sai dali rindo e saltitan-

do. Homem 2 enfim cai no choro).

\section{inquisição}

Personagens:

INQUISIDOR-MOR

INQUISIDOR COADJUVANTE

INQUISIDOR ESTAGIÁRIO

JOANA 
(Três grotescos inquisidores entram fazendo alarde. Suas expressões são tão esquisitas que, mesmo sisudos, acabam levando ao riso tamanho o ridículo de suas figuras deformadas. Cada um carrega uma sacolinha, pedindo dinheiro. Cantam uma musiquinha alegre e se movem freneticamente, com muita energia, paradoxalmente mantendo nas suas faces o mesmo rictus depressivo, de dor e de sofrimento. O Inquisidor-Estagiário, porém, como é um aprendiz, nem sempre consegue manter a expressão sofrida congelada no rosto...)

OS TRÊS - Ai! Ai-ai-ai-ai! Ai-ai-ai-ai-ai-ai-ai! E pega e mata e come e... Ui! Ui-ui-ui-ui! Ui-ui-ui-ui-ui-ui-ui! E bate e esfola e queima e ... Ai! Ai-ai-ai-ai! Ai-ai-ai-ai-ai-ai-ai! INQUISIDOR-MOR - Esta a Grande Visita da Inquisição, senhoras e senhores! Ao vivo, diretamente de (diz o local)!

INQUISIDOR-COADJUVANTE - Grande Visita da Inquisição!

INQUISIDOR-ESTAGIÁRIO - Grande Visita da Inquisição! A velha história de sempre em novo formato e em nova embalagem!

INQUISIDOR-MOR - Vamos chorar: uááááá! (Observa a platéia) Tá fraco. Mais empolgação nesse choro! Outra vez: uáááá! (Observa a platéia mais uma vez) Alegria, não! Eu falei empolgação! Vamos choraaar! Uááááá! (Observa a platéia e conclui erguendo os braços e gritando) Melhorou! (Noutro tom) Esta Visita conta com o patrocínio da Nova Igreja do Evangelho Digital.

INQUISIDOR-COADJUVANTE - Ligue agora para o número que aparece em sua tela e adquira qualquer peça do nosso material de merchandising. Cinquenta por cento off para os vinte primeiros compradores. As mais fantásticas imagens de violência e agonia em um grande sortimento de t-shirts, mouse-pads, bottons, stickers, postcards, posters e muito mais.

INQUISIDOR-ESTAGIÁRIO - Ligue já, senão...

INQUISIDOR-MOR - Inquisição do século XXI!

INQUISIDOR-COADJUVANTE - Uma vida muito melhor para você!

INQUISIDOR-ESTAGIÁRIO - Mas só depois que você morrer!

INQUISIDOR-MOR - O Paraíso vem aí! Não fique de fora.

INQUISIDOR-COADJUVANTE - Sofra agora e usufrua depois.

INQUISIDOR-ESTAGIÁRIO - Mas sofra mesmo, senão...

INQUISIDOR-MOR - Ligue agora e adquira já uma espetacular "Indulgência pós-extraordinária”. Garanta o perdão incondicional dos seus pecados. Descontos especiais para os planos empresa e familiar.

INQUISIDOR-COADJUVANTE - Plano master com perdão automático para falcatruas e mentiras em geral.

INQUISIDOR-ESTAGIÁRIO - Bônus purgatório para assassinatos não premeditados. INQUISIDOR-MOR - E o fantástico bônus purgatório plus para crimes hediondos.

INQUISIDOR-COADJUVANTE - Garanta o seu passaporte para o céu mediante quarentena no purgatório.

INQUISIDOR-ESTAGIÁRIO - Dinheiro na mão, garantia de perdão.

OS TRÊS - Está no ar, a Grande Visita da Inquisição!

(Silêncio)

INQUISIDOR-MOR - (Olhando para as pessoas ao redor, com expressão aterradora)

E aí?

INQUISIDOR-COADJUVANTE - (Olhando também, horrendo) E aí? Hem? 
INQUISIDOR-COADJUVANTE - (Olhando, com dificuldade de manter a concentração na máscara facial) E aí?

INQUISIDOR-MOR - É impressão minha ou tem muita gente feliz aqui, hoje?

INQUISIDOR-COADJUVANTE - Empolgação, sim!

INQUISIDOR-MOR - Felicidade, não!

INQUISIDOR-COADJUVANTE - Felicidade, não!

INQUISIDOR-MOR - Mas acontece que estou vendo muita gente feliz por aqui, não é, meu irmão?

INQUISIDOR-COADJUVANTE - É, meu irmão, é...

INQUISIDOR-MOR - Isso não é bom.

INQUISIDOR-ESTAGIÁRIO - É péssimo.

INQUISIDOR-COADJUVANTE - Gente feliz é muito perigosa.

INQUISIDOR-ESTAGIÁRIO - Evite a felicidade, senão...

INQUISIDOR-MOR - Todos com a cara feia! Já!

INQUISIDOR-ESTAGIÁRIO - Caras horríveis, muito horrorosas.

INQUISIDOR-COADJUVANTE - O sofrimento é fundamental neste mundo.

INQUISIDOR-MOR - Felicidade somente lá em cima.

INQUISIDOR-ESTAGIÁRIO - No céu!

OS TRÊS - E o caminho que leva até lá está em nossas mãos.

INQUISIDOR-MOR - Nosso programa começa agora.

INQUISIDOR-COADJUVANTE - Venha conosco!

INQUISIDOR-ESTAGIÁRIO - Nossa primeira atração vem aí.

INQUISIDOR-MOR - Vai começar agora...

INQUISIDOR-COADJUVANTE - O Grande Concurso S.O.K. de Sofrimento!

(Vinheta da empresa S.O.K. [Siderúrgica Oriental Kaiukoro], que pode ser audiovisual ou só áudio. Essa empresa fabrica instrumentos de tortura.)

INQUISIDOR-MOR - E esta foi a mensagem da S.O.K., cuidando de você com muito calor humano...

INQUISIDOR-COADJUVANTE - E desumano também!

INQUISIDOR-MOR - Queremos quatro voluntários da platéia! Quatro! Apenas quatro voluntários.

(Silêncio)

INQUISIDOR-MOR - Melhor se oferecerem logo, senão...

(O Coadjuvante e o Estagiário trazem quatro pessoas da platéia. O Inquisidor-mor pergunta seus nomes. O estagiário anota os nomes em adesivos e vai colando na roupa da pessoa correspondente, enquanto o Inquisidor prossegue os cumprimentos e a explicação)

INQUISIDOR-MOR - A proposta é muito fácil e instrutiva. Quem quiser fazer em casa, pode experimentar. Mamãe, papai, vovó, o gato, o cachorro, sofrimento é importante para toda a família. Quando eu contar até três, cada um vai fazer uma cara de sofrimento e ficar com essa cara congelada até eu dizer "acabou". Certo? Aquele que conseguir aparentar maior angústia e ansiedade ganhará um brinde da Inquisição. Atenção, platéia, o julgamento será feito por vocês. Concorrentes, preparar. Já! (Todos fazem a careta) Olhem bem, platéia. Escolham seu predileto ou predileta... dez segundos... nove... vejam esta cara aqui... esta outra... seis... escolham uma das quatro... três... escolheram o seu candidato? E... acabou! Vamos por aplausos. Palmas para o (nome do primeiro candidato)... palmas para a (nome do segundo 
candidato)...(etc). E o (nome de quem fez a careta melhor) ganhou! Epa, (nome de quem fez a careta melhor), não fique feliz. Controle-se. Levemente satisfeito e só, senão... Sicrano acaba de ganhar uma tatuagem de ferro em brasa, cortesia da S.O.K., Siderúrgica Oriental Kaiukoro. Palmas, minha gente. Obrigado pela participação de todos. É difícil manter o sofrimento dentro da gente, pessoal, eu sei, mas é necessário. Quando sorrimos ficamos vulneráveis e aí, coisas terríveis podem nos acontecer. INQUISIDOR-COADJUVANTE - Anote quem está com ar de riso.

(O Inquisidor-estagiário pega uma caderneta, começa a olhar atentamente para as pessoas, anotando de vez em quando)

INQUISIDOR-MOR - O nosso estagiário vai anotar quem está com dificuldade de manter-se no sofrimento. Não é por nada, não. É só para a gente ficar sabendo.

INQUISIDOR-COADJUVANTE - Queremos ajudar as pessoas a aprenderem o valor do sofrimento.

INQUISIDOR-MOR - Como alguém pode ser feliz com tanto sofrimento no mundo? INQUISIDOR-COADJUVANTE - É um acinte.

INQUISIDOR-MOR - Devemos sofrer juntos para honrar a dor dos nossos irmãos que estão sofrendo neste exato momento, em todas as partes do mundo.

INQUISIDOR-COADJUVANTE - Assim entendemos por que gente feliz é tão perigosa.

INQUISIDOR-MOR - É gente que não respeita a dor alheia.

INQUISIDOR-ESTAGIÁRIO - (Sorrindo, acreditando compreender o que se passa)

Gente feliz não tem medo de nada e esse tipo de gente é mais difícil da gente manipular.

INQUISIDOR-MOR - (Toma um susto com a fala do Inquisidor-Estagiário e fala para a platéia) E vocês aí não percam o controle! Senão... Voltamos daqui a pouco, depois dos nossos comerciais. (Para a técnica) Saímos do ar? Saímos? Ok. (Para o Inquisidor-Estagiário) Você está louco?

INQUISIDOR-ESTAGIÁRIO - O que foi que eu fiz?

INQUISIDOR-MOR - Só podia ser estagiário.

INQUISIDOR-ESTAGIÁRIO - Me respeite, senhor, que o meu sindicato funciona.

INQUISIDOR-MOR - Como é que você diz num programa ao vivo que gente feliz é mais difícil de controlar?

INQUISIDOR-ESTÁGIARIO - Eu me empolguei, eminência! Além do mais eu não falei nenhuma bobagem. Está escrito aqui, ó, no Manual do Inquisidor: gente feliz é realmente mais difícil de manipular.

(O Inquisidor-mor faz um gesto para que o Inquisidor-coadjuvante explique o que ele quer dizer)

INQUISIDOR-COADJUVANTE - Você não pode ficar recitando partes do Manual do Inquisidor para dois bilhões de espectadores. O conteúdo do Manual do Inquisidor é só para inquisidores. O nome já está dizendo. Manual do Inquisidor, entende?

INQUISIDOR-ESTAGIÁRIO - Foi mal. Desculpa aí, gente! Que mancada! Desculpa. Claro.

INQUISIDOR-COADJUVANTE - (Para o Inquisidor-Mor, como se ouvisse algo no ponto eletrônico) Dez segundos, eminência.

INQUISIDOR-ESTAGIÁRIO - (Fazendo uma mesura para o Inquisidor-mor) Perdão, senhor.

INQUISIDOR-MOR - Não.

INQUISIDOR-ESTAGIÁRIO - Perdão! Perdão! 
INQUISIDOR-MOR - Perdão coisa nenhuma. Quem comete um erro destes pode botar uma igreja abaixo num piscar de olhos.

(O Inquisidor-Coadjuvante amarra o estagiário)

INQUISIDOR-ESTAGIÁRIO - Oi? O que é isso?

INQUISIDOR-MOR - Exemplo.

INQUISIDOR-COADJUVANTE - Voltamos.

INQUISIDOR-MOR - (Noutro tom) E aqui estamos novamente com a nossa Grande Visita da Inquisição, que agora apresenta... (Faz um gesto ao Coadjuvante)

INQUISIDOR-COADJUVANTE - "Auto de Fé Especial”. Você vai presenciar a queima de um herege via satélite para todo o planeta. E não ouse mudar de canal, senão... INQUISIDOR-ESTAGIÁRIO - Ei, não podem fazer isso comi....

(O Inquisidor-coadjuvante amarra a boca do estagiário com um pano e joga um líquido sobre ele. O estagiário fica grunhindo)

INQUISIDOR-MOR - O herege é aquele que não concorda com a maioria e fica insistindo em obrigar as pessoas a verem o mundo como ele. Coitado. Não sabe que a maioria sempre vence, mesmo sem dar uma palavra... e, talvez, justamente por isso.

(O Inquisidor-coadjuvante acende uma tocha e se prepara para tocar fogo no estagiário)

INQUISIDOR-MOR - Não se preocupem, senhoras e senhores. A dor que esse herege vai sentir é a garantia de que ele irá diretamente para as portas do céu, afinal, todos sabem que é sofrendo hoje que a gente paga a felicidade do amanhã. Fogo nele, meu irmão.

(Surge Joana, com gestual de super-herói de série japonesa.)

JOANA - (Gritando) Kiai!

(Joana arrebata a tocha do Coadjuvante. Eles lutam e ela o nocauteia)

INQUISIDOR-MOR - Faça alguma coisa, meu irmão! Diretor! Técnicos! Façam algo! Alguém acuda! Onde está a polícia religiosa num hora destas?

JOANA - (Libertando o estagiário) Este reinado de mentiras está no fim... meu irmão! INQUISIDOR-MOR - Quem é você?

JOANA - (Fazendo uma coreografia de apresentação típica dos herois japoneses) Sou a Super Santa Joana Dark Neo-Pós-Everything e vou fazer você ter medo, muito medo de mim.

INQUISIDOR-MOR - Queimem a bruxa!

JOANA - Ahá! Eu não queimo. Sou 50\% espiritual e 50\% energia material. Voltei mais forte, melhor, mais avançada, quase invencível. Minha missão: invalidar a mentira com a força da lógica ululante e do óbvio redivivo!

INQUISIDOR-MOR - Não! Isso não pode ser verdade!

JOANA - Mas é! E como é! (Agarrando o Inquisidor-Mor e o Coadjuvante) Vamos.

INQUISIDOR-MOR - Não nos leve para o inferno, Dona Santa Joana. Esse negócio de sofrer é só da boca pra fora. Eu gosto mesmo é de um carinho.

JOANA - Quem não gosta? A minha ONG tem uma escola de reabilitação maravilhosa para vocês, com professores bem pagos e um índice de aproveitamento de $100 \%$ (Começa a sair com os dois)

INQUISIDOR-ESTAGIÁRIO - Santa Joana! E eu? O que vou fazer?

JOANA - Melhor desistir de sofrer, irmãozinho, senão...

(Joana sai carregando os inquisidores, ao som de um empolgante rock de super-herói). 